\title{
Solid-state NMR Characterization of Six-coordinated Ga(III) Complexes with Sulfur-donor Ligands
}

\author{
Seen-Ae Chae, ${ }^{\dagger}$ Oc Hee Han, ${ }^{\dagger+*}$ and Woo-Sik Jung ${ }^{*}$ \\ School of Chemical Engineering and Technologv. College of Engineering. Yeungnam Universitv. \\ Gvongsan 712-749, Korea. "E-mail: vising autu.ackr \\ Analvisis Research Division. Daegu Center. Korea Basic Science Institute, Daegu 702-701. Korea \\ E-mail: ohhan akbsirekr \\ Received August 10, 2009, Accepted September 8. 2009
}

Key Words: Ga(III) complexes. Dithiocarbamate complexes. Ga MAS NMR. ${ }^{15} \mathrm{~N}$ CPMAS NMR

Gallium has two isotopic nuclear magnetic resonince (NMR)-active nuclei ${ }^{69} \mathrm{Ga}$ and ${ }^{71} \mathrm{Ga}$ both of which have a common spin of $\mathrm{I}=3 / 2$ but different quadrupole moments. $\mathrm{Q}=$ $1.68 \times 10^{-29} \mathrm{~m}^{2}$ and $\mathrm{Q}=1.06 \times 10^{-99} \mathrm{~m}^{2}$. respectively. Aluminum, which is chemically similar to $\mathrm{Ga}$. has the quadrupole moment of $\mathrm{Q}=1.49 \times 10^{-29} \mathrm{~m}^{2}$ which is intermediate between those of ${ }^{69} \mathrm{Ga}$ and ${ }^{11} \mathrm{Ga}$. Well-resolved Ga magic angle spinning (MAS) NMR spectra are difficult to obtain because for a given electric field gradient (EFG) the central transitions (CTs) of ${ }^{69} \mathrm{Ga}$ and ${ }^{11} \mathrm{Ga}$ are broadened by a factor of about 11 and 4.8 . respectively. compared to that of ${ }^{\mathrm{Y}} \mathrm{Al} .{ }^{1}$ Of the relatively few studies on the Ga MAS NMR spectra of Ga(III) compounds. most of these compounds have had oxygen-donor ligands. In this work. the solid-state stnictures of two N.V-disubstituted dithiocarbamate complexes of trivalent gallium ion. $\mathrm{Ga}\left(\mathrm{S}_{2}\right.$

(C)
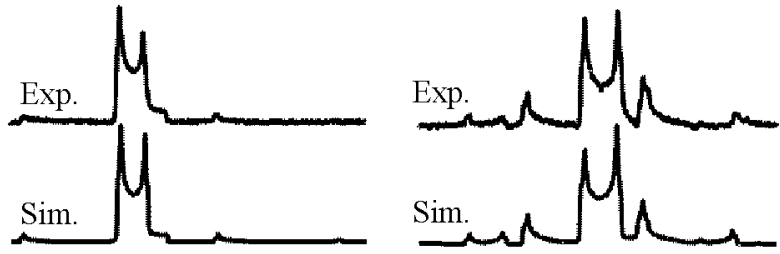

(B)
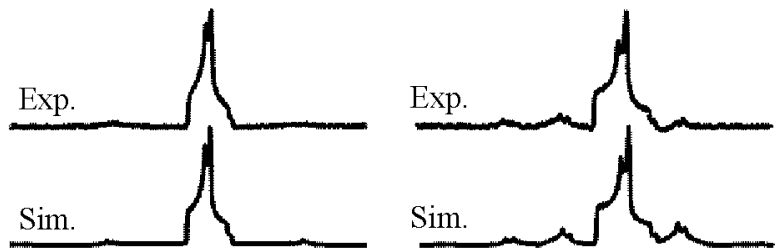

(A)
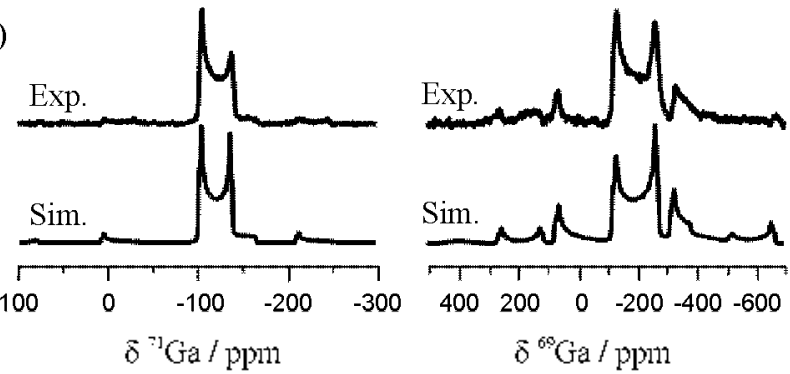

Figure 1. Experimental (top) and simulated (bottom) ${ }^{7 /} \mathrm{Ga}$ and ${ }^{50} \mathrm{Ga}$ MAS NMR spectra of (A) $\mathrm{Ga}\left(\mathrm{S}_{2} \mathrm{CNEt}_{2}\right)_{3}$, (B) $\mathrm{Ga}\left(\mathrm{S}_{2} \mathrm{CNM} \mathrm{e}_{2}\right)_{3}$, and (C) Ga(acac) 3 complexes.
$\left.\mathrm{CNR}_{2}\right)_{3}\left(\mathrm{R}=\mathrm{CH}_{3}\right.$ or $\left.\mathrm{C}_{2} \mathrm{H}_{5}\right)$ were characterized by ${ }^{71} \mathrm{Ga}$ and ${ }^{69}$ Ga MAS NMR spectroscopy. The dithiocarbamate ions. which are sulfur-donor ligands. form four-membered chelate rings with the gallium. thereby affording the pseudo-octahedral Ga(III) complexes. " The NMR parameters for the two complexes were conpared with those for tris(acetylacetonato) gallium(III). $\mathrm{Ga}(\mathrm{acac})_{2 .}$ in which the acetylacetonate ions form six-membered chelate rings with the gallium. ${ }^{3}$

Figure 1 shows the ${ }^{71} \mathrm{Ga}$ and ${ }^{69} \mathrm{Ga}$ MAS NMR spectra of $\mathrm{Ga}\left(\mathrm{S}_{2} \mathrm{CNEt}_{2}\right)_{3}$. $\mathrm{Ga}\left(\mathrm{S}_{2} \mathrm{CNMe}_{2}\right)_{3}$. and $\mathrm{Ga}(\mathrm{acac})_{3}$ complexes where $\mathrm{Et}=\mathrm{C}_{2} \mathrm{H}_{5}$ and $\mathrm{Me}=\mathrm{CH}_{3}$. The $\mathrm{CT}$ peaks in their "Ga MAS NMR spectra. which were measured at a spimning rate of 20 $\mathrm{kHz}$, displayed well-defined powder patterns for half-integer spin nuclei. On the other hand. the CT peaks in the ${ }^{69} \mathrm{Ga}$ MAS NMR spectra of the complexes other than $\mathrm{Ga}\left(\mathrm{S}_{2} \mathrm{CNMe}_{2}\right)_{3}$ did not exhibit the whole lineshape. although they were measured at a spinning rate of $28 \mathrm{kHz}$. To obtain NMR parameters such as the isotropic chemical shift $\left(\hat{o}_{i: i}\right)$. quadrupole coupling constant $\left(\mathrm{C}_{\mathrm{G}}\right)$. and asy'mmetry parameter $(\eta)$ in Table 1 , both ${ }^{71}$ Ga and ${ }^{69}$ Ga MAS NMR spectra were simulated using a STARS program (Varian Inc.). The ratio ( 1.59) of $C_{6}$ values of the "Ga and ${ }^{69} \mathrm{Ga}$ nuclei for each complex was almost equal to that $(1.58)$ of their quadrupole moments. The ${ }^{71} \mathrm{Ga} \mathrm{C}_{\text {i }}$ values obtained in this work were comparable to those of ${ }^{71} \mathrm{Ga}$ nuclei in the octahedral sites $\left(\mathrm{GaO}_{6}\right)$ in $\mathrm{MgGa}_{2} \mathrm{O}_{4}\left(\mathrm{C}_{\mathrm{i}}=7.6 \mathrm{MHz}\right)$ and $\mathrm{Y}_{3} \mathrm{Ga}_{5} \mathrm{O}_{12}\left(\mathrm{C}_{\mathrm{Q}}=4.1 \mathrm{MHz}\right)$, and decreased in the following order, as listed in Table 1: $\mathrm{Ga}\left(\mathrm{S}_{2} \mathrm{CNE}_{2}\right)_{\mathbf{s}}>\mathrm{Ga}(\mathrm{acac})_{3}>\mathrm{Ga}$ $\left(\mathrm{S}_{2} \mathrm{CNMe}\right)_{3}$. The slightly smaller $\mathrm{C}_{1}$ value for the $\mathrm{Ga}\left(\mathrm{S}_{2} \mathrm{CNMe}_{2}\right)_{3}$ complex compared to that for the $\mathrm{Ga}\left(\mathrm{S}_{2} \mathrm{CNE}_{2}\right)_{2}$ complex indicated that the electronic structure around the Ga nucleus in the former complex was less deviated from spherical symmetry than that in the latter complex. Massiot et al. presented a linear

Table 1. NMR parameters obtained by simulating " $\mathrm{Ga}$ and ${ }^{60} \mathrm{Ga}$ MAS NMR spectra of $\left.\mathrm{Ga}\left(\mathrm{S}_{2} \mathrm{CNEt}\right)_{2}\right)_{3}, \mathrm{Ga}\left(\mathrm{S}_{2} \mathrm{CNM} \mathrm{e}_{2}\right)_{3}$, and $\mathrm{Ga}(\mathrm{acac})_{3}$ complexes

\begin{tabular}{lcccc}
\hline \multirow{2}{*}{ Complex } & $\delta_{\text {isc }}$ & \multicolumn{2}{c}{$\mathrm{C}_{\mathrm{Q}}(\mathrm{MHz})$} & \multirow{2}{*}{$\eta$} \\
\cline { 3 - 4 } & $(\mathrm{ppm})$ & ${ }^{\overline{1} \mathrm{Ga}}$ & ${ }^{59} \mathrm{Ga}$ & \\
\hline $\left.\mathrm{Ga}\left(\mathrm{S}_{2} \mathrm{CNEt}\right)_{2}\right]_{3}$ & $-90.0 \pm 2.0$ & 6.3 & 10.0 & 0.09 \\
$\mathrm{Ga}\left(\mathrm{S}_{2} \mathrm{CNMe}_{2}\right)_{3}$ & $-98.0 \pm 0.1$ & 5.0 & 8.0 & 0.75 \\
$\mathrm{Ga}(\mathrm{acac})_{3}$ & $-10.5 \pm 0.5$ & 5.9 & 9.3 & 0.12 \\
\hline
\end{tabular}


(B)
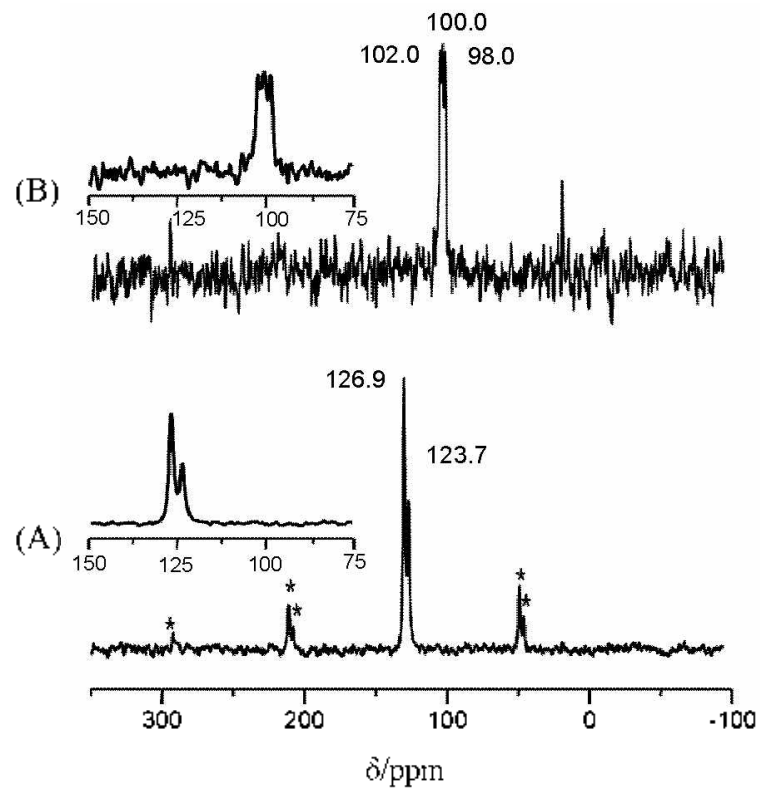

Figure 2. Experimental "N CP MAS NMR spectra of (A) Ga ( $\mathrm{S}_{2} \mathrm{CNE} \mathrm{L}_{2}$ ), at a spinning rale of $5 \mathrm{kl} \mathrm{k}$ and a conlact time of $5 \mathrm{~ms}$ and (B) $\mathrm{Ga}\left(\mathrm{S}_{2} \mathrm{CNM} \mathrm{N}_{2}\right)_{3}$ at a spinting rate of $7 \mathrm{kHz}$ and a contact time of $3 \mathrm{~ms}$. The spiming side bands are marked by asterisks.

correlation. with a scale factor of 3.1 for ${ }^{-1} \mathrm{Ga} /{ }^{7} \mathrm{Al}$. between the EFG values of ${ }^{-1} \mathrm{Ga}$ and ${ }^{27} \mathrm{Al}$ for structurally analogous $\mathrm{Ga}$ and $\mathrm{Al}$ compounds in which only oxvgen atoms occupy the first coordination sphere. ${ }^{4}$ Considering that the reported ${ }^{-1} \mathrm{Al}$ $\mathrm{C}_{6}$ value in tris(acetylacetonato aluminum(III). Al(acac) $)_{3}$ is

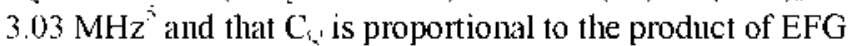
and quadrupole moment. the estimated ratio of EFG values of $\mathrm{Ga}(\mathrm{acac})_{3}$ 1o $\mathrm{Al}(\mathrm{acac})_{3}$ was 2.7. which was close to the Massiot's scale factor

The $\eta$ value reflects the deviation from electronic crlindrical symmetry around the rucleus. The $\eta$ value for the $\mathrm{Ga}\left(\mathrm{S}_{2} \mathrm{CNMc}_{2}\right)_{3}$ complex in a triclinic crystal sy $\mathrm{stcm}^{2}$ was nuuch larger than that for the $\mathrm{Ga}\left(\mathrm{S}_{2} \mathrm{CNEt}\right)_{3}$ and $\mathrm{Ga}(\mathrm{acac})_{3}$ complexes in monoclinic crystal systems. ${ }^{3 \pi}$ This difference in the cxplained theoretically in terms of the ery stal system and the local sy minetry of a complex unit. Howerer. since llie quantpolar parameters such as $C_{\square}$ and $\eta$ are more strongly influenced by electric fields in closer distances, the $\eta$ values are mainly deternined by the local symmetry of a complex unit. The difference in the symmetry between $\mathrm{Ga}\left(\mathrm{S}_{2} \mathrm{CNE}_{2}\right)_{3}$ and $\mathrm{Ga}$ $\left(\mathrm{S}_{2} \mathrm{CNMe}_{2}\right)_{3}$ complexes was also reflected in their ${ }^{15} \mathrm{~N}$ cross polarization (CP) MAS spectra. As shown in Figure 2, the ${ }^{15} \mathrm{~N}$ CP MAS spectrum of the $\mathrm{Ga}\left(\mathrm{S}_{2} \mathrm{CNE} I_{2}\right)_{3}$ complex with a 2-fold axis showed two peaks at $\delta 126.9$ and 123.7. the area ratio of which was $c a .2: 1$, while that of the $\mathrm{Ga}\left(\mathrm{S}_{2} \mathrm{CNMe}_{2}\right)_{3}$ complex, which has no 2-fold axis. showed three peraks at 0 102.0. 100.0. and 98.0. The $\eta$ value (0.12) for the Ga(acac) 3 complex was rery similar to that $(0.15)^{5}$ for the Al(acac); complex. The lower signal-to-noise ratio for the spectrum of $\mathrm{Ga}\left(\mathrm{S}_{2} \mathrm{CNMe}_{2}\right)_{3}$ in Figure 2(B) than that of $\mathrm{Ga}\left(\mathrm{S}_{2} \mathrm{CNEt}_{2}\right)_{3}$ in Figure 2(A) is due to the lower efficiency of $\mathrm{CP}$ for Ga $\left(\mathrm{S}_{2} \mathrm{CNMc}_{2}\right)$. The higher mobility of terminal methy] group in $\mathrm{Ga}\left(\mathrm{S}_{2} \mathrm{CNMe}_{2}\right)_{3}$ induces weaker ${ }^{15} \mathrm{~N}$ signal by $\mathrm{CP}$ from the methy I protons than from the metlylene in $\mathrm{Ga}\left(\mathrm{S}_{2} \mathrm{CNE} 1_{2}\right)_{\text {. }}$.

The Ga chemical shifts of the six-coordinate gallium conpounds with only oxygen atoms in the first coordination sphere range from -80 to $74 \mathrm{ppm}$. complexes with chalcogen-donor atoms tends to increase in the following order: $\mathrm{O}<\mathrm{S}<\mathrm{Sc}$. Thereforc. the Ga nuclei in $\mathrm{Ga}\left(\mathrm{S}_{2} \mathrm{CNMe}_{2}\right)_{3}$; and $\mathrm{Ga}\left(\mathrm{S}_{2} \mathrm{CNEt}\right)_{3}$; complexes were more shielded than those in the six-coordinate gallium compounds with oxygen-donor ligands and also than those in the fourcoordinate gallium compounds with sulfur-donor ligands such as $\gamma$-Ga_ $\mathrm{S}_{\text {i. }}{ }^{.}$As listed in Table 1. the resonance of the $\mathrm{Ga}\left(\mathrm{S}_{2}\right.$ $\left.\mathrm{CNMe}_{2}\right)_{3}$ complex was more shielded than that of the $\mathrm{Ga}\left(\mathrm{S}_{2} \mathrm{C}-\right.$ $\mathrm{NE}_{-}$); complex. Consistent with our results. in their liquid-state

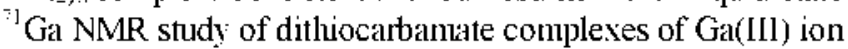
Dutla et al. showed that the resonance was deshiclded with increasing steric hindrance of the $\mathrm{R}$ group in $\mathrm{Ga}\left(\mathrm{S}_{2} \mathrm{CNR}_{2}\right)_{3}{ }^{161}$ Massiot et al. found a linear correlation. $\delta\left("{ }^{\prime \prime} \mathrm{Ga}\right)(\mathrm{ppm})=2.84 \times$ $\delta\left({ }^{\prime \prime} \mathrm{Al}\right)(\mathrm{ppm})-1$. between ${ }^{2-} \mathrm{Al}$ and ${ }^{31} \mathrm{Ga}$ chemical shifts for stnicturally analogous $\mathrm{Al}$ and $\mathrm{Ga}$ compounds in which only oxygen atoms occupy the first coordination sphere. The new chemical shift point, $(0,-10.5)$. for Al(acac) s and $\mathrm{Ga}(\mathrm{acac})_{3}$ was slightly deviated from the correlation line.

In conclusion. Ga MAS NMR spectra of six-coordinate gallium complexes with sulfur-donor ligands were acquired and their NMR parameters were deternined. The $\mathrm{C}_{6}$ values for pseudo-octahedral Ga( $\left.\mathrm{S}_{2} \mathrm{CNMe}_{2}\right)_{3}$ and $\mathrm{Ga}\left(\mathrm{S}_{2} \mathrm{CNE}_{2}\right)_{3}$ complexes were comparable to those for the octahedral site $\left(\mathrm{GaO}_{6}\right)$ in various gallium oxides. The difference in the $\eta$ values between $\mathrm{Ga}\left(\mathrm{S}_{2} \mathrm{CNMe}_{2}\right)_{3}$ and $\mathrm{Ga}\left(\mathrm{S}_{2} \mathrm{CNEt}\right)_{3}$ complexes was explaincd in terns of the symmetry of complexes and was also reflected in their ${ }^{1.5} \mathrm{~N}$ CP MAS NMR spectra.

\section{Experimental Section}

The method for synthesizing $\mathrm{Ga}\left(\mathrm{S}_{2} \mathrm{CNE}_{2}\right)$, and $\mathrm{Ga}\left(\mathrm{S}_{2} \mathrm{CN}\right.$ $\left.\mathrm{Me}_{2}\right)_{3}$ complexes has been described in a previous paper. ${ }^{9} \mathrm{The}$ $\mathrm{Ga}(\mathrm{acac})_{3}$ powder $(99.99 \%$ purity) was purcliased from Aldrich and used without any further purification. ${ }^{1} \mathrm{H} .{ }^{13} \mathrm{C}$, and ${ }^{7]} \mathrm{Ga}$ NMR spectra of the three complexes dissolved in $\mathrm{CDCl}_{3}$ were obtained on a Varian Unity INOVA 500 spectrometer with the following results: 'H NMR: for $\mathrm{Ga}\left(\mathrm{S}_{2} \mathrm{CNMe}_{2}\right)_{3}$. o 3.41 (s. $\left.-\mathrm{CH}_{3}\right)$ : for $\mathrm{Ga}\left(\mathrm{S}_{2} \mathrm{CNEt}_{2}\right)_{3} . \delta 1.30\left(\mathrm{l} . J=7.2 \mathrm{H} \%-\mathrm{CH}_{3}\right)$. $\delta 3.79$ (q. $J=7.2 \mathrm{~Hz} .-\mathrm{CH}_{z}$ ); for $\mathrm{Ga}(\mathrm{acac}){ }_{3} . \delta 2.0 \mathrm{l}$ (s. $-\mathrm{CH}_{3}$ ). $\delta$ 5.43 (s. $-\mathrm{CH}=)$. ${ }^{1.3} \mathrm{C} \mathrm{NMR}$ : for $\mathrm{Ga}\left(\mathrm{S}_{2} \mathrm{CNMc} \mathrm{C}_{2}\right)_{3} . \bar{\delta}+5.1\left(-\mathrm{CH}_{3}\right)$. o $202.5(>\mathrm{C}-\mathrm{N})$ : for $\mathrm{Ga}\left(\mathrm{S}_{2} \mathrm{CNEt}\right)_{3}$. o $12.1\left(-\mathrm{CH}_{3}\right), \delta$ o 49.5 $\left(-\mathrm{CH}_{2}-\right), \delta 201.1(>\mathrm{C}-\mathrm{N}):$ for $\mathrm{Ga}(\mathrm{acac})_{3} . \delta \bar{\delta} 27.3\left(-\mathrm{CH}_{3}\right), \delta$ $100.3(-\mathrm{CH}=) . \delta 192.9(\mathrm{C}=\mathrm{O}) .{ }^{-1} \mathrm{Ga}$ NMR: for $\mathrm{Ga}\left(\mathrm{S}_{2} \mathrm{CNMc}\right)_{3 .}$. $\delta$-96.8: for $\mathrm{Ga}\left(\mathrm{S}_{2} \mathrm{CNEt}_{2}\right)_{3}, \hat{o}-86.2$; for $\mathrm{Ga}(\mathrm{acac})$. $\delta$ o -10.1

Solid-state ${ }^{-1}$ Ga and ${ }^{-3}$ Ga NMR spectra were acquired at $1+.1 \mathrm{~T}$ on a Unity INOVA 600 spectrometer using $2.5 \mathrm{~mm}$ zirconia rotors. The pulse widths for excitation were $1 \mu$ for ${ }^{-1} \mathrm{Ga}$ and $2 \mu \mathrm{s}$ for ${ }^{699} \mathrm{Ga}$ with a pulse repetition delay time of $2 \mathrm{~s}$. Transients between $102+$ and 3000 were accumulated for acquiring the spectra. The chemical shifts of ${ }^{-1} \mathrm{Ga}$ and ${ }^{(6)} \mathrm{Ga}$ were referenced to external I $\mathrm{M}$ aqueous gallium(III) nitrate solution. Nitrogen-15 CP MAS NMR spectra were also measured on a Unity INOVA 600 spectrometer with an $\mathrm{H} / \mathrm{X} \mathrm{CP}$ MAS probe cquipped with $5 \mathrm{~mm}$ zirconia rotors. The proton $\pi / 2$ 
pulse for $\mathrm{CP}$ was $7 \mu$ s. A variable amplitude CP method that is insensitive $C P$ efficiency to spinning rates was used for improved CP efficiency at high spinning rates. The pulse repetition delay time was $5 \mathrm{~s}$. Transients between 5000 and 30000 were accumulated for acquiring the spectra. Chemical shifts of ${ }^{15} \mathrm{~N}$ were referenced to extemal $\mathrm{NH}_{4} \mathrm{Cl}$ powder.

Acknowledgments. This research was supported by the Yeungnam University research grants in 2008.

\section{References}

1. MacKenzie, K. J. D.; Smith, M. E. Afritinucledr Solid-state MIR of Inorganic Materials, Pergamon l faterials Series, Iol. 6 ; Pergannon Press: Oxford, U. K., 2002; Chap. 10.
2. Andrews, P. C.: Lawrence, S. M.: Raston, C. L.: Skelton, B. W, Tolhurst, V.-A.; White, A. H.; Sheppard, L. M. Inorg. Chim. fcta 2000, 300-302, 56

3. Dymock, K.: Palenik, G. I. Acta Cnst. 1974, B30, 1364.

4. Massiot, D.: Vosegaars, T.; Magneron, N.: Trumean, D.; Montouillot, V.: Berthet, P.; Loiseall, T.; Bujoli, B. Solid State Kucl. Magn. Reson. 1999, 15, 159.

5. Schurko, R. W.; Wasylishshen, R. E.: Foerster, H. J. Phus. Chem. A 1998, 102,9750

6. Dymock, K.; Palenik, G. I. J. Chem. Soc. Dalton 1976, 28.

7. Bradley, S. M.; Howe, R. F.; Kydd, R. A. Magnt Reson. Chem. $1993,31,883$.

8. Redder, D. Magn. Reson. Rev. 1984, 9, 125.

9. Jung. W.-S.; Ra, C. S.; Mir, B.-K. Bull Korean Chem. Soc. $2005,26,131$.

10. Dutta, D. P.; Tain, V. K.; Knoedler, A.; Kaim, W. Polwhedron $2002,21,239$. 